\title{
Strategies for Successful College Transitions for High School Students in Urban Schools
}

\author{
Erin L. Lewis, The University of North Carolina at Charlotte
}

Students in the U.S. are underachieving in math and reading, which negatively affects transitions to postsecondary education (NAEP, 2015). Research shows that students' exposure to college coursework in high school can increase academic outcomes for students and lead to successful transitions to college. However, many studies promote the use of early college programs that foster college readiness without considering schools that may not be equipped to provide those opportunities for students. This article offers insight about the lack of college readiness for students, specifically students that attend urban schools, and the role that high schools play in combating these limitations. This article concludes with recommendations on ways to creatively immerse students from urban schools with college experiences.

Keywords: College and career readiness, transition, high school

Imagine it is the first semester of your freshman year of college. You are taking a full-time load, including your introductory freshman English writing course. You have always excelled in grade school, but now something is wrong. Some of the texts that you are assigned to read are hard to comprehend. Your midterm is an eight-page paper, but the longest paper you have ever written was only four pages. Anxiety sets in. You begin to question everything. I used to make all A's, what happened? Am I actually smart? Can I do this? Will I flunk out of college? This is the reality for many of today's college students who went through the P-12 system believing they were excellent scholars, yet struggle to make passing grades as first-year college students. The question remains as to how students are experiencing situations similar to the scenario above when college and career readiness is a top priority in the U.S. educational system (U.S. Department of Education, n.d.). 
According to the National Assessment on Educational Progress (2015), $37 \%$ of 12 th grade students are considered college and career ready in reading and $25 \%$ are considered college and career ready in math. In addition, the National Center for Education Statistics (2018) reported that 59.8\% of students graduated from college in six years, which is considered $150 \%$ of normal time for college completion. These data have many implications about college preparedness and the impact on college completion. High school students are not adequately prepared to meet the academic rigor of college and close to half of first-year college students are enrolled in remedial math and/or English courses (Jimenez, Sargrad, Morales, \& Thompson, 2016). College readiness is crucial for students transitioning to a college or university. Therefore, it is necessary to improve college readiness for high school students as a significant step toward a successful transition to college.

Subsequently, socioeconomic status has been linked to educational achievement and students from low socioeconomic status (low SES) families have been deemed less likely to obtain a bachelor's degree (Redford \& Hoyer, 2017; Slavin, Cheung, Holmes, Madden, \& Chamberlain, 2013). Therefore, supports for students from low SES backgrounds are especially needed. When considering support for low SES students, it is also important to acknowledge the intersectional factors of race and class that are reflected through the data. The Status and Trends in the Education of Racial and Ethnic Groups 2017 reported that in 2014 the percentage of Black, American Indian/ Alaskan Native, Hispanic, and Pacific Islander children living in poverty was higher than the percentages of Asian and White children living in poverty (Musu-Gillette et al., 2017). That same report disaggregated the percentage of undergraduate student enrollment by race and ethnicity; this showed that Asian, American Indian/Alaskan Native, and students that identified with two or more races had the lowest percentages of students enrolled in college in 2014 (Musu-Gillette et al., 2017). Thus, it is important that solutions for increasing successful college transitions should emphasize non-white students from low SES backgrounds. 


\section{Table 1. Race, Poverty, and College Enrollment Rates}

\begin{tabular}{lll} 
Race/Ethnicity & $\begin{array}{l}\text { Percentage of children } \\
\text { under age 18 living in } \\
\text { poverty, by race/ } \\
\text { ethnicity: 2014 }\end{array}$ & $\begin{array}{l}\text { Percentage of distribution } \\
\text { of total undergraduate } \\
\text { student enrollment in } \\
\text { degree-granting institutions, } \\
\text { by race/ethnicty:2014 }\end{array}$ \\
\hline White & $12 \%$ & $57 \%$ \\
\hline Black & $38 \%$ & $14 \%$ \\
\hline Hispanic & $32 \%$ & $18 \%$ \\
\hline Asian & $12 \%$ & $6 \%$ \\
\hline Pacific Islander & $27 \%$ & No data \\
\hline American Indian & $35 \%$ & $1 \%$ \\
\hline Two or more races & $22 \%$ & $3 \%$ \\
\hline
\end{tabular}

Note. This table uses U.S. Department of Commerce, Census Bureau, American Community Survey (ACS) data and National Center for Education Statistics, Integrated Postsecondary Education Data System (IPEDS), "Fall Enrollment Survey" to show the percentages of students living in poverty by race/ethnicity in comparison to undergraduate enrollment by race/ethnicity as listed in the Status and Trends in Education of Racial and Ethnic Groups 2017. Both data sets contain data from 2014. There was no percentage on undergraduate enrollment for Pacific Islander students in 2014.

\section{College and Career Readiness}

The passing of the No Child Left Behind Act of 2001 (NCLB) has been deemed a major turning point for education reform in the U.S. (McGuinn, 2015; Scott \& Holme, 2016). The No Child Left Behind Act of 2001 drastically impacted the current U.S. education system by requiring high stakes annual testing in math and reading, data disaggregation based on subgroup categories, mandated proficiency targets, and repercussions for underperforming schools (McGuinn, 2015). Another significant outcome of NCLB was the creation of national standards for U.S. education. The Common Core standards were finalized in 
2010 and were intended to "address what students are expected to know and understand by the time they graduate from high school" (Common Core Standards [CCSSI], n.d.). Common Core Standards placed college and career readiness as a major educational priority in the United States.

\section{Successful Transitions to College}

Recent studies on college and career readiness for students have highlighted the important role that high school plays in preparing students for successful transitions to college. Royster, Gross, and Hochbein (2015) examined the impact that students' college aspirations, academic plans, and participation in extracurricular activities had on their performance on the ACT college entrance exam and concluded that starting college preparation as early as 8th grade is beneficial to students. Vargas, Hooker, and Gerwin (2017) analyzed the blurred lines that exist between colleges and high schools due to early college programs. Vargas et al. (2017) advocated for college transitions to begin in high school:

It is more important than ever for high school to prepare young people for what lies ahead and propel them toward the degrees and certificates that hold the key to achieving their professional and personal ambitions. One proven way to do that is through immersive college experiences. (Vargas et al., 2017, p.17)

Ndiaye and Wolfe (2016) asserted that exposure to college level coursework in high school increases the chance of high school graduation and the likelihood of students remaining resilient through their first year of college. While research studies have concluded the need for high schools to support students in their college transitions through the promotion of early college and dual enrollment programs, the studies failed to acknowledge how these supports could occur in schools lacking the resources needed to successfully immerse students' in college experiences. Thus the cycle continues in which a student's socioeconomic status becomes a potential barrier to a successful college transition. The remainder of this article will describe and outline concrete steps that high school teachers can take to support high school students from low SES backgrounds in successfully transitioning to college regardless of the existence of an early college program in their schools. Teachers in urban high schools are specifically addressed, as many urban schools have larger 
populations of students of color as well as students from low SES backgrounds (Scott \& Holme, 2016). Recommendations for high school counselors and college admissions staff are also included.

\section{Recommendations for High School Educators in Urban Schools}

When schools are unable to provide students with specific resources and services necessary for academic and personal growth, teachers make the decision to stick to the script and serve students with what they have, or they decide to get creative. The opportunity for students to enroll in early college programs clearly puts those participating students at an advantage once they transition to college. However, one students' advantage becomes another student's disadvantage, which can demotivate the student with the missed opportunity (Destin \& Kosko, 2016). As such, the teachers of students in underserved schools can embed college preparation into their curriculum through the following two strategies.

One strategy that high school teachers in urban schools can use to support students' college transitions is by providing students opportunities to practice completing assignments similar to assignments that would be completed for the same course subject on the collegiate level. In order to immerse students with college-level assignments and class activities, the high school teacher would need to align their class assignment to a college professor's class assignment. High school teachers in urban schools should seek out college faculty in their discipline and reach out for examples or suggestions for assignments that will expose students to the type of work that will be expected of them on the collegiate level. Another strategy that urban high school teachers can use is to invite back recent graduates that have similar backgrounds to their current students to come share their personal experiences about transitioning to college. Recent graduates that are accomplishing their desired goal can motivate current students by serving as an example that can help students begin to see themselves as college students and develop the belief that college success is attainable (Destin \& Kosko, 2016; Schneider, 2015). 


\section{Recommendations for High School Counselors and College Admissions Offices}

To equip high school students with additional resources that support college readiness, high school counselors and college admissions staff should develop partnerships that bridge the gap between high school and the college or university. One way this partnership could occur would be for college admissions staff to develop a network of school counselors that they frequently correspond with to share news or updates about their college admissions process; counselors can then share this information with their high school students. College admissions staff could also offer workshops or webinars for school counselors to attend and learn more about admissions criteria. Educating school counselors about current admissions criteria will allow the counselors to better support students in their course determinations and the college application process, because they will know exactly what the student's perspective college is seeking. Lastly, school counselors could coordinate college information sessions for students and parents at the high school campus. Ultimately, professional relationships between high school counselors and college admissions staff allow both parties to improve enrollment and transitions to college for high school students.

\section{Conclusion}

High school students are transitioning to college without being adequately prepared to succeed. This is evident through national testing data for 12th grade students and remedial course enrollment rates in colleges and universities. In addition, college and career readiness has become a focus of the U.S. educational system that has yet to yield increased postsecondary outcomes for students. Research on college and career readiness for high school students has promoted early college programs and dual-enrollment opportunities. Yet, the research fails to address schools that may be underresourced and unable to provide students access to college immersion programs. Urban schools are often lacking resources while serving large populations of non-white students and students from lower socioeconomic statuses. As a result, teachers in urban schools have to choose whether or not to strategically engage students in college preparatory work within the 
classroom. High school teachers and school counselors in urban schools can increase their students' access to college readiness programming and resources by partnering with college faculty and staff. By incorporating these strategies into schools, student achievement and college and career readiness will increase, and in turn will improve urban students' transitions to college. 


\section{References}

Common Core State Standards Initiative. (n.d.). Development process.

Retrieved from http://www.corestandards.org/about-the-standards/ development-process/

Destin, M., \& Kosko, M. (2016). Motivating disadvantaged students toward the possibility of college. The Phi Delta Kappan, 97(5), 8-12. Retrieved from http://www.jstor.org/stable/24579771

Jimenez, L., Sargrad, S., \& Thompson, M. (2016, September). Remedial education: The cost of catching up (Rep.). Retrieved from https:// cdn.americanprogress.org/content/uploads/2016/09/29120402/ CostOfCatchingUp 2-report.pdf

McGuinn, P. (2015). Schooling the state: ESEA and the evolution of the U.S. Department of Education. RSF: The Russell Sage Foundation Journal of the Social Sciences, 1(3), 77-94. doi:10.7758/rsf.2015.1.3.04

Musu-Gillette, L., de Brey, C., McFarland, J., Hussar, W., Sonnenberg, W., \& Wilkinson-Flicker, S. (2017). Status and trends in the education of racial and ethnic groups 2017 (NCES 2017-051). U.S. Department of Education, National Center for Education Statistics. Washington, DC. Retrieved [date] from http://nces.ed.gov/pubsearch.

National Assessment of Educational Progress. (2015). 2015 mathematics and reading at grade 12. National Center of Education Statistics, Institute of Education Sciences. Retrieved from https://www.nationsreportcard. gov/reading_math_g12_2015/\#reading/preparedness

Ndiaye, M., \& Wolfe, R. (2016). Early college can boost college success rates for low-income, first-generation students. The Phi Delta Kappan, 97(5), 32-37. Retrieved from http://www.jstor.org.librarylink.uncc.edu/ stable/24579775

Redford, J., \& Hoyer, K.M. (2017). First generation and continuing-generation college students: A comparison of high school and postsecondary experiences (NCES 2018-009). U.S. Department of Education. Washington, DC: National Center for Education Statistics. Retrieved from https://nces.ed.gov/pubsearch/ pubsinfo.asp?pubid=2018009. 
Royster, P., Gross, J., \& Hochbein, C. (2015). Timing is everything: Getting students back on track to college readiness in high school. The High School Journal, 98(3), 208-225. Retrieved from http://www.jstor.org/ stable/44075294

Schneider, B. (2015). The college ambition program: A realistic transition strategy for traditionally disadvantaged students. Educational Researcher, 44(7), 394-403. Retrieved from http://www.jstor.org/ stable/24571336

Scott, J., \& Holme, J. J. (2016). The political economy of market-based educational policies. Review of Research in Education, 40(1), 250-297. DOI: $10.3102 / 0091732 X 16681001$

Slavin, R., Cheung, A., Holmes, G., Madden, N., \& Chamberlain, A. (2013). Effects of a data-driven district reform model on state assessment outcomes. American Educational Research Journal, 50(2), 371-396. Retrieved from http://www.jstor.org.librarylink.uncc.edu/stable/23526145

U.S. Department of Education. (n.d.). College- and Career-Ready Standards. Retrieved from https://www.ed.gov/k-12reforms/standards

U.S. Department of Education, National Center for Education Statistics. (2018). The Condition of Education 2018 (NCES 2018-144), Undergraduate Retention and Graduation Rates. Retrieved from https://nces.ed.gov/ pubsearch/pubsinfo.asp?pubid=2018144

Vargas, J., Hooker, S., \& Gerwin, C. (2017). Blending high school and college can sharpen the focus of each. The Phi Delta Kappan, 99(3), 13-18. Retrieved from http://www.jstor.org/stable/26388244 